Jurnal Olahraga \& Kesehatan Indonesia

Volume 1 Nomor 1 (2020)

E-ISSN: 2747-061X

available online at https://jurnal.stokbinaguna.ac.id/index.php/jok

\title{
PROFIL KONDISI FISIK ATLET ARUNG JERAM
}

\author{
Aristiyanto $^{1}$ *, Fredy Eko Setiawan ${ }^{2}$, Hadi Subagya ${ }^{3}$, Nurohman ${ }^{4}$ \\ ${ }^{123}$ Universitas Ngudi Waluyo, Jawa Tengah, Indonesia, 50512 \\ ${ }^{4}$ SMP Negeri 2 Punggelan, Jawa Tengah, Indonesia, 53414 \\ *Coressponding Author: aristiyanto@unw.ac.id
}

\section{Keterangan}

Rekam Jejak:

Received, Oktober 2020

Revised, November 2020

Accepted, Desember 2020

Kata Kunci:

Kondisi Fisik, Atlet, Arung

Jeram
Abstrak

Penelitian ini bertujuan untuk mengetahui tingkat kondisi fisik atlet cabang olahraga Arung Jeram KONI Banjarnegara dalam rangka persiapan menghadapi Pekan Olahraga Kedu Pekalongan dan Banyumas (PORDULONGMAS). Metode pada penelitian ini menggunakan metode analisis deskriptif. Populasi pada penelitian ini adalah atlet cabang olahraga arung jeram KONI Banjarnegara yang berjumlah 16 orang. Sampel pada penelitian ini menggunakan total sampling. Teknik pengambilan data menggunakan tes pengukuran kondisi fisik yang meliputi daya tahan cardiovascular, daya tahan otot lengan, kekuatan otot tangan kanan dan kiri, kekuatan otot punggung, kekuatan dan power kaki, kekuatan otot perut, dan kelentukan. Berdasarkan hasil tes pengukuran kondisi fisik atlet arung jeram Kabupaten Banjarnegara menunjukkan bahwa daya tahan cardiovascular rata-rata adalah 33,71 masuk katergori kurang. Rata-rata daya tahan otot lengan 48,44 pada kategori sangat baik, rata-rata kekuatan otot tangan kanan 35,91 pada kategori kurang, sedangkan rata-rata kekuatan tangan kiri 33,69 pada kategori cukup. Ratarata kekuatan otot punggung 106,50 berada pada kategori baik, kekuatan otot kaki 99,91 pada kategori sangat kurang, rata-rata power kaki 38,50 berada pada kategori kurang, rata-rata kekuatan otot perut 52,31 pada kategori sangat baik, dan rata-rata kelentukan 14,07 pada kategori sangat kurang. 


\section{PENDAHULUAN}

Arung Jeram atau rafting adalah suatu aktivitas manusia dalam mengarungi sungai dengan mengandalkan keterampilan dan kekuatan fisiknya untuk mendayung perahu yang berbahan lunak yang secara umum diterima sebagai suatu kegiatan sosial, komersil dan olahraga (IRF, 1997, p. 1). Arung Jeram sering juga disebut dengan Olahraga Arus Deras (ORAD) yang memiliki nilai olahraga, petualangan, dan rekreasi. Olahraga Arung Jeram (white water rafting) sebagai olahraga mengarungi sungai berjeram dengan mengunakan wahana tertentu yang terdiri dari perahu karet, kayak, kano dan dayung dengan tujuan rekreasi maupun ekspedisi (Darsono, 2008). Kegiatan arung jeram dimulai setelah Perang Dunia ke-II dimana sekelompok pencinta kegiatan adventure mencoba menelusuri sungai-sungai di Colorado. Dari hanya menggunakan perahu karet bekas PD II, kegiatan ini berkembang menjadi satu aktivitas dengan berbagai wahana seperti kayak, canoe, dan lain-lain (FAJI, 2020) saat itu powell melakukannya dengan perahu kecil yang tersusun dari papan kayu (Soekirno, 2006).

Melihat arung jeram secara khusus pada kajian prestasi bagi Kabupaten Banjarnegara esensi dari olahraga prestasi adalah pengelolaan kepelatihan untuk meraih prestasi di berbagai pertandingan, baik nasional maupun internasional. Dibutuhkan perencanaan yang matang, efektif, holistik sehingga mampu mengantarkan para atlet untuk berprestasi (FAJI, 2020, p. 2), untuk itu pada penelitian ini akan menganalisis kodisi fisik atlet arung jeram Banjarnegara dalam rangka persiapan mejelang Pekan Olahraga Kedu, Pekalongan, dan Banyumas (PORDULONGMAS), hal ini karena arung jeram merupakan salah satu cabang andalan Banjarnegara dalam meraih medali emas. Lebih menarik lagi bahwa Banjarnegara diuntungkan secara geografis dengan adanya sungai Serayu yang memiliki track lintasan berstandar nasional. Bahkan potensi alam Sungai Serayu untuk berlatih arung jeram ini dapat dimaksimalkan untuk membina atlet di Banjarnegara (Banyumas, 2019).

Prestasi cabang olah raga arung jeram Banjarnegara pada Porprov 2018 berhasil meraih dua medali emas. Bertanding di venue Sungai Elo Magelang, atlet Porprov Banjarnegara terlihat cukup menguasai medan. Emas pertama dari arung jeram berasal dari nomor Head to Head (H2H) Rafting 4 (R4) Putra pada Sabtu (20/10). Sedangkan Emas selanjutnya berasal dari nomor Slalom H2H R4 Putra (Banyumas, 2018). Salah satu faktor penentu dalam mencapai prestasi olahraga adalah terpenuhinya faktor kondisi fisik, yang terdiri dari kekuatan, kecepatan, kelincahan, koordinasi, tenaga, daya tahan otot, daya kerja jantung dan paru-paru, kelentukan, kecepatan reaksi dan kesehatan untuk berolahraga (Sajoto, 1995, p. 2) Besar kemungkinan salah satu permasalahan yang menyebabkan atlet tidak meraih prestasi yang maksimal diakibatkan adanya kelemahan pada kondisi fisik (Ritonga, 2013, p. 3)

Selama ini belum diketahui secara pasti sebarapa bagus kondisi fisik atlet arung jeram Kabupaten Banjarnegara melalui pendekatan Sport science dengan metode tes dan pengukuran. Hal ini yang perlu menjadi perhatian bagi KONI Kabupaten Banjarnegara dalam mempersiapkan atletnya menghadapi turnamen atau pertandingan, khususnya dalam rangka mempersiapakan diri menghadapi Pekan Olahraga Dulongmas tahun 2021. Berdasarkan pemaparan di atas penulis tertarik untuk mengkaji lebih lanjut tentang, bagaimana kondisi fisik atlet arung jeram KONI Kabupaten Banjarnegara? Penelitian ini difokuskan pada pengukuran kondisi fisik sesuai dengan faktor dominan pada cabang olahraga arung jeram yang akan dibahas pada metode hasil pembahasan berikut ini.

\section{METODE}

Metode yang dipergunakan dalam penelitian ini adalah menggunakan metode analisis deskriptif yang merupakan penelitian yang berusaha mendeskripsikan suatu gejala, peristiwa, kejadian yang terjadi pada saat sekarang (Sudjana, 2001, p. 64) atau penelitian yang menyelidiki keadaan, kondisi atau hal lain-lain yang sudah disebutkan, yang hasilnya dipaparkan dalam bentuk laporan penelitian (Arikunto, 2013) dengan pendekatan kuantitatif yang bertujuan untuk 
mendeskripsikan atau menjelaskan peristiwa atau suatu kejadian yang terjadi pada saat sekarang dalam bentuk angka-angka yang bermakna (Sudjana, 2004, p. 53) atau data penelitian berupa angka-angka dan analisis menggunakan statistik (Sugiyono, 2012).

Populasi merupakan wilayah generalisasi yang terdiri atas objek/subjek yang mempunyai kualitas dan karakteristik tertentu yang ditetapkan oleh peneliti untuk dipelajari dan kemudian ditarik kesimpulannya (Sugiyono, 2010, p. 117). Populasi pada penelitian ini adalah atlet cabang olahraga arung jeram KONI Banjarnegara yang berjumlah 16 orang. Sampel adalah sebagian atau wakil dari populasi yang akan diteliti (Arikunto, 2010) pada penelitian ini menggunakan total sampling. Teknik pengambilan data menggunakan tes pengukuran kondisi fisik yang meliputi:

- Daya tahan kardiovaskular, pengukuran terhadap daya tahan cardiovascular diperlukan untuk mengetahui status tingkat kebugaran atlet menggukan Multi Stage Fitness Tes (MFT). Kebugaran yang ideal akan berpengaruh terhadap pencapaian prestasi atau performa (Aristiyanto, 2020, p. 50).

- Daya tahan otot lengan, pengukuran daya tahan otot diperlukan untuk mengetahui tingkat ketahanan otot lengan menggunakan tes Push Up (Surahman et al., 2018, p. 22).

- Kekuatan otot tangan kanan dan kiri, pengukuran kekuatan otot tangan diperlukan untutk mengukur kekuatan otot tangan kanan dan kiri dengan menggunakan Handgrip Dynamometer.

- Kekuatan otot punggung, pengukuran kekuatan otot punggung diperlukan untuk mengetahui tingkat kekuatan otot punggung menggunakan Back Dynamometer.

- Kekuatan otot kaki, diperlukan untuk mengetahui tingkat kekuatan otot tungkai menggunakan Leg Dynamometer.

- Power kaki, diperlukan untuk mengukur daya ledak otot tungkai menggunakan Vertical Jump.

- Kekuatan otot perut, diperlukan untuk mengetahui tingkat kekuatan otot perut menggunakan tes Sit Up.

- Kelentukan diperlukan untuk mengukur tingkat kelentukan atlet dengan menggunakan tes Sit and Reach

\section{HASIL \& PEMBAHASAN}

Hasil

Berdasarkan penjelasan dan urian di atas, maka didapatkan hasil penelitian yang telah dilaksanakan adalah sebagaimana berikut ini;

Multi-stage Fitness Test (MFT)

Berdasarkan Multi-stage Fitness Test (MFT) yang telah dilakukan, maka diperoleh hasil yang dijabarkan pada tabel berikut ini:

Tabel 1. Hasil Multi-stage Fitness Test (MFT)

\begin{tabular}{ccc}
\hline Kategori & Frekuensi & Persentase \\
Sangat Baik & 0 & 0,00 \\
Baik & 1 & 6,25 \\
Cukup & 6 & 37,50 \\
Kurang & 8 & 50,00 \\
Sangat Kurang & 1 & 6,25 \\
\hline
\end{tabular}

Berdasarkan tabel 1 diatas dapat diketahui bahwa kondisi daya tahan cardiovascular $\left(\mathrm{VO}_{2} \mathrm{Max}\right)$ pada 16 atlet arung jeram Kabupaten Banjarnegara terdapat 1 atlet sebesar 6,25\% termasuk pada kategori baik, kemudian terdapat 6 atlet atau 37,50\% termasuk pada kategori cukup, terdapat 8 atlet atau 50\% dengan kategori kurang, terdapat 1 atlet sebesar 6,25\% termasuk kategori sangat kurang dan tidak ada atlet dengan kategori sangat baik. 
Tes Push Up

Berdasarkan tes Push Up yang telah dilakukan, maka diperoleh hasil yang dijabarkan pada tabel berikut ini:

Tabel 2. Hasil Tes Push Up

\begin{tabular}{ccc}
\hline Kategori & Frekuensi & Persentase \\
Sangat Baik & 14 & 87,5 \\
Baik & 1 & 6,25 \\
Cukup & 1 & 6,25 \\
Kurang & 0 & 0 \\
Sangat Kurang & $\underline{0}$ & $\underline{0}$ \\
\hline
\end{tabular}

Berdasarkan tabel 2 diatas dapat diketahui bahwa kondisi daya tahan lengan pada 16 atlet arung jeram Kabupaten Banjarnegara terdapat 14 atlet atau 87,5\% dengan kategori sangat baik, terdapat 1 atlet sebesar 6,25\% termasuk pada kategori baik, kemudian terdapat 1 atlet atau $6,25 \%$ termasuk pada kategori cukup, dan tidak ada atlet dengan kategori kurang ataupun sangat kurang.

Tes Handgrip Dynamometer

Berdasarkan tes Handgrip Dynamometer yang telah dilakukan, maka diperoleh hasil yang dijabarkan pada tabel berikut ini:

Tabel 3. Hasil Tes Handgrip Dynamometer

\begin{tabular}{ccccc}
\hline Kategori & Frekuensi Kanan & Persentase & Frekuensi Kiri & Persentase \\
Sangat Baik & 1 & 6,25 & 3 & 18,75 \\
Baik & 2 & 12,5 & 5 & 31,25 \\
Cukup & 6 & 37,5 & 6 & 37,5 \\
Kurang & 5 & 31,25 & 2 & 12,5 \\
Sangat Kurang & 2 & 12,5 & 0 & 0 \\
\hline
\end{tabular}

Berdasarkan tabel 3 diatas dapat diketahui bahwa kondisi kekuatan tangan kanan pada 16 atlet arung jeram Kabupaten Banjarnegara terdapat 1 atlet atau 6,25\% dengan kategori sangat baik, terdapat 2 atlet sebesar $12,5 \%$ termasuk pada kategori baik, kemudian terdapat 6 atlet atau 37,5\% termasuk pada kategori cukup, dan terdapat 5 atlet atau 31,25\% masuk kategori kurang dan terdapat 2 atlet atau 12,5\% termasuk dalam kategori sangat kurang. Kekuatan otot pada tangan kiri terdapat 3 atlet atau $18,75 \%$ termasuk kategori sangat baik, 5 atlet atau $31,25 \%$ pada kategori baik, 6 atlet atau 37,5\% termasuk kategori cukup, terdapat 2 atlet atau 12,5\% kategori kurang dan tidak ada atlet yang masuk dalam kategori sangat kurang.

Tes Back Dynamometer

Berdasarkan tes Back Dynamometer yang telah dilakukan, maka diperoleh hasil yang dijabarkan pada tabel berikut ini:

Tabel 4. Hasil Tes Back Dynamometer

\begin{tabular}{ccc}
\multicolumn{2}{c}{ Tabel 4. Hasil Tes Back Dynamometer } \\
\hline Kategori & Frekuensi & Persentase \\
Sangat Baik & 8 & 50 \\
Baik & 6 & 37,5 \\
Cukup & 2 & 12,5 \\
Kurang & 0 & 0 \\
Sangat Kurang & $\underline{0}$ & $\underline{0}$ \\
\hline
\end{tabular}


Berdasarkan tabel 4 diatas dapat diketahui bahwa kondisi kekuatan otot punggung pada 16 atlet arung jeram Kabupaten Banjarnegara adalah terdapat 8 atlet atau 50\% dengan kategori sangat baik, terdapat 6 atlet sebesar 37,5\% pada kategori baik, kemudian terdapat 2 atlet atau 12,5\% termasuk pada kategori cukup, dan tidak ada atlet dengan kategori kurang ataupun sangat kurang.

Tes Leg Dynamometer

Berdasarkan tes Leg Dynamometer yang telah dilakukan, maka diperoleh hasil yang dijabarkan pada tabel berikut ini:

Tabel 5. Hasil Tes Leg Dynamometer

\begin{tabular}{ccc}
\hline Kategori & Frekuensi & Persentase \\
Sangat Baik & 0 & 0 \\
Baik & 1 & 6,25 \\
Cukup & 6 & 37,5 \\
Kurang & 1 & 6,25 \\
Sangat Kurang & 8 & 50 \\
\hline
\end{tabular}

Berdasarkan tabel 5 diatas dapat diketahui bahwa kondisi kekuatan otot tungkai pada 16 atlet arung jeram Kabupaten Banjarnegara terdapat 1 atlet atau 6,25\% dengan kategori baik, terdapat 6 atlet sebesar 37,5\% pada kategori cukup, terdapat 1 atlet atau 6,25\% termasuk pada kategori kurang, terdapat 8 atlet atau $50 \%$ pada kategori sangat kurang, dan tidak ada atlet dengan kategori sangat baik.

Tes Vertical Jump

Berdasarkan tes Vertikal Jump yang telah dilakukan, maka diperoleh hasil yang dijabarkan pada tabel berikut ini:

Tabel 6. Hasil Tes Vertical Jump

\begin{tabular}{ccc}
\hline & Trekuensi & Persentase \\
Kategori & 0 & 0 \\
Sangat Baik & 1 & 6,25 \\
Baik & 5 & 31,25 \\
Cukup & 5 & 31,25 \\
Kurang & 5 & 31,25 \\
Sangat Kurang & &
\end{tabular}

Berdasarkan tabel 6 diatas dapat diketahui bahwa kondisi daya ledak (power) otot tungkai pada 16 atlet arung jeram Kabupaten Banjarnegara terdapat 1 atlet atau 6,25\% dengan kategori baik, terdapat 5 atlet sebesar $31,25 \%$ pada kategori cukup, terdapat 5 atlet atau 31,25\% termasuk pada kategori kurang, terdapat 5 atlet atau 31,25\% pada kategori sangat kurang, dan tidak ada atlet dengan kategori sangat baik.

Tes Sit Up

Berdasarkan tes Sit $U p$ yang telah dilakukan, maka diperoleh hasil yang dijabarkan pada tabel berikut ini:

Tabel 7. Hasil Tes Sit Up

\begin{tabular}{ccc}
\hline Kategori & Frekuensi & Persentase \\
Sangat Baik & 14 & 87,5 \\
Baik & 1 & 6,25 \\
Cukup & 0 & 0 \\
Kurang & 1 & 6,25 \\
Sangat Kurang & $\underline{0}$ & $\underline{0}$ \\
\hline
\end{tabular}


Berdasarkan tabel 7 diatas dapat diketahui bahwa kondisi kekuatan otot perut pada 16 atlet arung jeram Kabupaten Banjarnegara terdapat 14 atlet atau 87,5\% dengan kategori sangat baik, terdapat 1 atlet sebesar 6,25\% pada kategori baik, terdapat 1 atlet atau 6,25\% termasuk pada kategori kurang, dan tidak ada atlet dengan kategori cukup dan sangat kurang.

Tes Sit and Reach

Berdasarkan tes Sit and Reach yang telah dilakukan, maka diperoleh hasil yang dijabarkan pada tabel berikut ini:

Tabel 8. Hasil Tes Sit and Reach

\begin{tabular}{ccc} 
Kategori & Frekuensi & Persentase \\
Sangat Baik & 1 & 6,25 \\
Baik & 1 & 6,25 \\
Cukup & 2 & 12,5 \\
Kurang & 1 & 6,25 \\
Sangat Kurang & $\underline{68,75}$ \\
\hline
\end{tabular}

Berdasarkan tabel 8 diatas dapat diketahui bahwa kondisi kelentukan pada 16 atlet arung jeram Kabupaten Banjarnegara terdapat 1 atlet atau 6,25\% pada kategori sangat baik, terdapat 1 atlet atau 6,25\% dengan kategori baik, terdapat 2 atlet sebesar $12,5 \%$ pada kategori cukup, terdapat 1 atlet atau 6,25\% termasuk pada kategori kurang, dan 11 atlet atau $68,75 \%$ dengan kategori sangat kurang.

\section{Pembahasan}

Daya tahan kardiovaskular berhuhungan dengan kemampuan sistem kerja jantung (Setijono \& Pd, 2017, p. 8). Daya tahan kardiovaskular yang sistem kerjanya menggunakan oksigen dinamakan kardiovaskular aerob sedangkan daya tahan yang dalam sistem kerjanya tidak menggunakan oksigen di sebut dengan kardivaskular anaerob. Sistem energi pada cabang olahraga arung jeram dominan menggunakan metabolisme anaerobik yang biasanya menghasilkan asam laktat (Putri Taufany, 2020, p. 2). Pada olahraga ini sangat dibutuhkan kondisi fisik yang prima atau atlet harus memiliki kapasitas vo $_{2}$ max yang baik. Berdasarkan hasil tes diketahui bahwa kondisi daya tahan kardiovaskular atlet arung jerang kabupaten Banjarnegara rata-rata adalah 33,71 masuk katergori kurang.

Kekuatan otot tangan dan daya tahan otot lengan merupakan kondisi fisik yang sangat dibutuhkan pada olahraga arung jeram, mengingat kekuatan adalah kemampuan sekelompok otot dalam menahan beban secara maksimal (Nurhasan, 2005) sedangkan Daya tahan otot adalah kapasitas sekelompok otot untuk melakukan kontraksi yang terus menerus saat menahan suatu beban submaksimal dalam jangka waktu tertentu (RI, 2019). Berdasarkan hasil tes diketahui bahwa kekuatan otot tangan kanan rata-rata atlet arung jeram Banjarnegara adalah 35,91 berada pada kategori kurang, untuk kekuatan otot tangan kiri sebesar 33,69 pada kategori cukup, sedangkan rata-rata daya tahan otot lengan adalah 48,44 berada pada kategori sangat baik, kekuatan otot tangan dan daya tahan otot lengan ini berfungsi sebagai faktor utama dalam menggerakkan dan menahan laju perahu di atas jeram.

Kemudian kekuatan otot kaki pada olahraga arung jeram yang berfungsi sebagai tahanan dalam mempertahankan keseimbangan atlet ketika mendayung perahu yang didukung oleh kekuatan otot perut dan kekuatan otot punggung. Berdasarkan hasil tes maka diketahui bahwa kekuatan otot kaki rata-rata atlet arung jeram Banjarnegara adalah 99,91 termasuk dalam kategori sangat kurang, sedangkan power tungkai rata-rata adalah 38,50 pada kategori kurang. Untuk kekuatan otot perut rata-rata atlet arung jeram Banjarnegara adalah 48,44 berada pada kategori sangat baik, sedangkan kekuatan otot punggung rata-rata adalah 106,50 berada pada kategori baik.

Kelentukan sangat diperlukan oleh atlet arung jeram, kelentukan merupakan persyaratan yang diperlukan bagi berlangsungnya gerak bagi manusia. Hal ini karena gerakan yang ditampilkan dapat lebih harmonis dan ritmis jika ditunjang 
oleh kelentukan tubuh yang baik (Suharti, 2016, p. 519). Pada olahraga arung jeram fleksibilitas bagi atlet sangat menunjang penampilan dalam menghasilkan gerakan ritmis dan harmonis, berdasarkan hasil tes telah diketahui bahwa kelentukan atlet arung jeram Banjarnegara adalah 14,07 berada pada kategori sangat kurang.

\section{SIMPULAN}

Kondisi fisik atlet merupakan salah satu aspek penting pada olahraga prestasi, setelah itu baru teknik dan taktik dapat berjalan dengan optimal bilamana atlet memiliki tingkat kondisi fisik yang sangat baik. Aspek kondisi fisik merupakan bagian terpenting dalam semua cabang olahraga, terutama untuk mendukung aspek-aspek lainnya seperti; mental, teknik, taktik dan strategi dalam bertanding atau berlomba (Swadesi, 2016). Kondisi fisik pada olahraga prestasi merupakan bagian yang fundamental, hal ini karena kondisi fisik sangat menunjang aspek yang lain. Berdasarkan hasil penelitian dan pembahasan di atas maka dapat disimpulkan bahwa: tingkat kondisi fisik atlet arung jeram Banjarnegara memiliki kondisi fisik dengan kategori baik adalah pada kekuatan otot punggung, kekuatan otot perut, dan daya tahan otot lengan. Namun diperlukan perhatian dan latihan khusus pada komponen fisik daya tahan kardiovaskular, kelentukan, power otot kaki, kekuatan otot tungkai dan kekuatan otot tangan.

\section{DAFTAR PUSTAKA}

Arikunto, S. (2013). Prosedur Penelitian Suatu Pendekatan Praktik. PT. Rhineka Cipta.

Aristiyanto, A. (2020). The Relationship Between Physical Fitness, Discipline and Motivation of UNNES Security Performance. 50. https://doi.org/10.4108/eai.22-7-2020.2300251

Banyumas, R. (2018, October 22). Arung Jeram Banjarnegara Raih Dua Emas. Radar Banyumas, 1. https://radarbanyumas.co.id/arung-jeram-banjarnegara-raih-dua-emas/

Banyumas, R. (2019, November 8). Kontingen Arung Jeram Jateng Juarai Kejurnas. JUMAT, 8 NOVEMBER 2019 Sumber: Https://Radarbanyumas.Co.Id/Kontingen-Arung-JeramJateng-Juarai-Kejurnas/Copyright (C) Radarbanyumas.Co.Id, 1. https://radarbanyumas.co.id/kontingen-arung-jeram-jateng-juarai-kejurnas/

Darsono. (2008). Olahraga Alam. Parca.

FAJI, F. A. J. I. (2020a). Pendahuluan. Federasi Arung Jeram Indonesia. http://www.faji.org/pendahuluan.php

FAJI, F. A. J. I. (2020b). Perencanaan Prestasi. Faji.Org. http://www.faji.org/binpres.php

IRF, I. R. F. (1997). About International Rafting Federation. International Rafting Federation Offiicial. https://www.internationalrafting.com/about/irf/\#: :text=Definition of Rafting,the raft's direction and speed.

Nurhasan. (2005). Aktivitas Kebugaran. Depdiknas.

Putri Taufany. (2020). Pengaruh Recovery Active Terhadap Penurunan Kadar Asam Laktat Pada Atlet Arung Jeram Dki Jakarta [Universitas Negeri Jakarta]. http://repository.unj.ac.id/

RI, P. K. (2019). Latihan Fisik Meningkatkan Kekuatan dan Daya Tahan Otot. Kementrian Kesehatan Republik Indonesia. http://www.p2ptm.kemkes.go.id/

Ritonga, L. (2013). Profil kondisi fisik atlet arung jeram putra Mapala Unimed 2013. (p. 3). UNIMED.

Sajoto, M. (1995). Peningkatan \& Pembinaan Kekuatan Kondisi Fisik Dalam Olah Raga (Revisi). Dahara Prize.

Setijono, P. H. H., \& Pd, M. (2017). Evaluasi Anthropometri dan Kondisi Fisik Atlet Futsal Bintang Timur Surabaya. Jurnal Prestasi Olahraga, 2(1), 1-11. https://jurnalmahasiswa.unesa.ac.id/index.php/jurnal-prestasi- 
olahraga/article/view/21680

Soekirno, A. M. (2006). Arung Jeram Menelusuri Tantangan Membangun Kematangan. Insight Solusi Mandiri.

Sudjana, D. (2001). Metode \& Teknik Pembelajaran Partisipatif. Falah Production.

Sudjana, D. (2004). Pendidikan Nonformal. Falah Production.

Sugiyono. (2010). Metode Penelitian Pendidikan Pendekatan Kuantitatif, kualitatif, dan R\&D. Alfabeta.

Sugiyono. (2012). Metode Penelitian Kuantitatif Kualitatif dan R\&B. Alfabeta.

Suharti. (2016). Perkembangan Gerak: Kelentukan (Flexibility). Gelora, Jurnal Pendidikan

Olahraga Dan Kesehatan IKIP Mataram, 3(2), 519. https://karyailmiah.unipasby.ac.id/

Surahman, H. B., Kanca, I. N., \& Tisna, G. D. (2018). Pengaruh Pelatihan Bermain Bulutangkis Overhead Clear Drill Terhadap Kekuatan Dan Daya Tahan Otot Lengan. Jurnal Ilmu Keolahragaan Undiksha, 6(3), 0-7. https://doi.org/10.23887/jiku.v6i3.2650

Swadesi, I. K. I. (2016). Standardisasi Kondisi Fisik Atlet Porprov Bali. SEMINAR NASIONAL RISET INOVATIF (SENARI) KE-4 TAHUN 2016, 152-160.

eproceeding.undhiksa.ac.id 